\title{
HUMAN HEALTH IN A RISK SOCIETY
}

\section{ЗДОРОВ’Я ЛЮДИНИ У СУСПІЛЬСТВІ РИЗИКУ}

\section{Lydiia Gazniuk $^{1}$ \\ Yuliia Semenova ${ }^{2}$}

DOI: https://doi.org/10.30525/978-9934-588-15-0-100

Abstract. Human health in a risk society is conceived of as a special way of being-in-the-world, which correlates with condition of existential harmony between personal somatic being and social being, in which its existence is not intensely autonomous to society, but is thought holistically. The personal context of lack of health in the presence of morbid conditions is manifested in the urge to rethink the axiological space of the individual, openness to oneself, interaction with society at a new spiritual and existential level. The condition of a person's physical health depends on the state of his spiritual health, and in order to maintain and save a person's health, it is necessary to improve and harmonize one's own living space, to balance individual morality with social standards, and to transform the utilitarian attitude to his own health into value-worldview. The subject of the study is nanobiotechnology as mechanisms for the implementation of the modus operandi in the risk society. The methodological basis of the study is based on a systematic approach that aims at: identifying elements of nanobiotechnology and their specific effects on the health of the individual; study of the causal connection between mental, physical, and mental processes in human being; maintaining and restoring the normal functioning of the human body as a coherent system, resulting from the synergistic effect of the struggle of opposing forces in its structure. The ideas of transhumanism and postanthropology are heuristically fruitful in understanding human health issues in risk society. The modus of health is a system of interactions between the individual, nature and society, which are components of the complete spir-

\footnotetext{
${ }^{1}$ Dr. habil. in Philosophy, Full Professor, Head of Department of Humanities, Kharkiv State Academy of Physical Culture, Ukraine

${ }^{2}$ Ph.D. in Philosophy, Associate Professor, Professor at Department of Humanities, Kharkiv State Academy of Physical Culture, Ukraine
} 
itual and moral stability of man and society, ecological harmony, the possibility of self-realization in its social efficiency. The importance of nanobiotechnology as a high-tech opportunity for transforming unhealthy health through impact on the human body is considered. The human dimension of nanobiotechnology of health lies in mediating biological technologies of human relations, integrating humans into the technosphere, and transforming them into an element of technical reality. Solving health problems with the help of nanobiotechnology leads to the desacralization of health, the disappearance of the need for spiritual human ac-tivity, the shift of emphasis on the vertical values of the human spirit from spiritual to physical. Given the mythologization of nanobiotechnology and the natural and scientific incompetence of the majority of the population, the hoax of scientific achievements and manipulation of consciousness in the formation of public opinion on the implementation of nanobiotechnological achievements in life is activated not a rational, but emotional and sensualworldly. Medicalization is a socio-cultural phenomenon that interacts with the individual on a spiritual level. In the process of medicalization the world outlook of the person, his attitude to his own health, to himself and other people in social life changes; the culture, the means, the conditions and the ways of solving health problems that are considered as a medical problem as a result of the medicalization process are modified. Among the socio-cultural consequences of the medicalization process are the following: the formation of patient consciousness, tendencies to pathologize and autopathologize the life of society and a particular person; stimulating excessive concern for one's health and, at the same time, alienating one's self, destroying one's self-analysis ability, reconciling one's inner world.

\section{1. Вступ}

Сучасне суспільство потребує оптимізації соціального розвитку завдяки глибокій індивідуалізації життєдіяльності людини, при наявності ефективного інструментарію для управління процесом формування і використання здоров'я/енергії людини у суспільстві ризику. Потреба у дослідженні впливу нанобіотехнологій на здоров'я людини нині особливо загострюється у зв'язку з необхідністю управляти оздоровчими процесами. Для вивчення питання щодо застосуванняя нанобіотехнологій для підтримки і покращення здоров'я людини існують 
світоглядні, технологічні та організаційні підстави. Проблематику здоров'я людини актуалізують у суспільстві ризику, коли людина почасти потрапляє в екстремальні умови життя, де даються взнаки: когнітивні причини, які свідчать про недостатню обізнаність суспільства 3 теоретичними знаннями стосовно здоров'я; онтологічні причини, які вказують на те, що здоров'я людини обумовлює усі відомі процеси природного і соціального життя і його ресурсозабезпечення; екологічні причини, які приховують небезпечні загрози здоров'ю людини масштабними катастрофами; праксеологічні причини, які загострюють проблему формування, зберігання і використання життєвих, особливо енергетичних, психічних та інтелектуальних ресурсів людини.

Сутність застосування нанобіотехнологій полягає в організаційно-управлінському підході людини до власного організму з його фізичними і психічними особливостями та духовними настановами як «турбота про себе», тобто про своє тіло, душу і здоров'я в цілому. Об'єктом дослідження є здоров'я людини як атрибутивний стан іiі персонального буття і соціальна цінність. Предметом дослідження $\epsilon$ нанобіотехнології як механізми реалізації модусу здоров'я у суспільстві ризику. Методологічна основа дослідження базується на системному підході, який спрямований на: виявлення елементів нанобіотехнологій та їх специфічних впливів на стан здоров'я індивіда; вивчення причинно-наслідкового зв'язку між ментальними, фізичними та психічними процесами в бутті людини; підтримання і відтворення нормального функціонування організму людини як цілісної системи, що виникає у результаті синергетичного ефекту боротьби протилежних сил у його структурі.

\section{2. Механізми реалізації здоров'я в контексті розвитку біологічної науки}

Модус здоров'я є показником характеру людини і науки у суспільстві ризику. Прагматична інструментальна оцінка науково-технічної революції і новітніх технологій дозволяє зробити висновок про необхідність впровадження антропосоціокультурних практик, які можуть бути корисними при вирішенні конкретних проблем. Проте, природничо-науковий підхід до явищ соціокультурного буття людини іманентно містить у собі значну кількість філософських аспектів, які необхідно 
враховувати для забезпечення соціального прогресу без ризику для життя і здоров'я людини.

Поняття «здоров'я» розглядається 3 трьох основних позицій: фізичне, психічне і власне соціальне здоров'я. В межах гносеологічного підходу феномен здоров'я розглядається як інтегративний показник сукупності певних об'єктивних і суб'єктивних характеристик особистості. Філософський зміст категорії «здоров'я» містить такий спосіб існування людини, який характеризується наявністю гармонії при взаємодії двох людських світів: внутрішнього і зовнішнього. У суспільстві ризику варто розрізняти соціальне здоров'я людини та здоров'я суспільства. Соціокультурне буття людини складає єдність персонального та соціального буття. Людина проявляє свій життєвий потенціал у процесі власної життєдіяльності, задаючи напрямок і реалізуючи прагнення людської активності в екзистенційній установці «турботи про себе». Соціокультурне буття людини, як сфера суспільного існування особистості, конституюється смислом. Здоров'я людини постає у вигляді моделі гармонійної взаємодії суспільства та особистості в процесі їі життєдіяльності, що забезпечуватиме повноцінну персональну самореалізацію. Поняття здоров'я суспільства характеризує стан соціуму як цілісного системного утворення, «здорове суспільство - це ефективне, згідно з кінцевими критеріями оцінки його життєдіяльності, су-спільство» [7, с. 3]. Для популяційного рівня здоров'я характерними $є$ біологічні хвороби із суспільним характером, що залежить від свідомості та інших соціально-психологічних факторів. Е. Фромм зазначає, що здорове суспільство - «це суспільство, в якому такі якості, як жадібність, схильність до експлуатації і володіння та самолюбування неможливо використовувати для досягнення матеріальної вигоди і зростання особистого престижу» [11, с. 315]. Таке суспільство має бути побудованим на засадах людської солідарності, де можливо, будучи хазяїном свого життя, впливати на життя суспільства. I головне - суспільство не має суперечити природі людини і іiі внутрішній конституції, у протилежному разі це буде суспільство ризику. Поняття «здоров'я суспільства» повинно містити у собі ідею внутрішньої узгодженості, злагодженої взаємодії індивіда та соціального організму, а також гармонійної взаємодії суспільства із природним середовищем. Здоров'я суспільства являє собою своєрідний 
індикатор духовно-морального стану індивідів, що укладає гармонійні соціальні і екологічні відносини.

Застосування системного підходу до розгляду суспільства передбачає врахування можливості впливу різних факторів на його стан. Одним із таких факторів можна назвати розвиток і впровадження науково-технічних інновацій у повсякденне буття. Саме тому надзвичайно актуальною $є$ потреба дослідження впливу сучасних досягнень новітньої техніки і високих технологій на здоров'я людини та здоров'я суспільства. Механізми реалізації здоров'я людини у суспільстві ризику пов'язані саме з новітніми високими технологіями і особливо біотехнологіями як засобами осмислення проблеми здоров'я і обумовлені тим, що дані технології можуть виступати у ролі високотехнологічних засобів для трансформації хвороби у здоров'я завдяки втручанню і впливу на організм і тіло людини. Поняття здоров’я і засоби його забезпечення нерозривно пов'язані із медичними практиками як соціальними технологіями, які задовольняють специфічні потреби людей в медичній допомозі. Слід зазначити, що на сучасному етапі розвитку науки переважна більшість відкриттів робиться саме у біологічній науці, що характеризується посиленням впливу біології та суміжних з нею наук на суспільне життя. Це стосується такої проблеми як ідентифікація особи, яка все частіше відбувається із застосуванням біометричних даних. Надзвичайної актуальності набули також питання, пов'язані зі стрімким розвитком та зростанням популярності технологій оперування біологічним матеріалом, які використовуються в різних галузях медицини і спрямовані на вдосконалення фізичного стану людини, підтримання іiі здоров'я і продовження терміну життя. Міждисциплінарний потенціал біології і біотехнологій піднімає важливі проблеми, як природознавчого, так і суспільного характеру. Сьогодні людство стоїть на порозі біотехнологічної революції, і біотехнологія сьогодні $є$ комплексною науково-практичною галуззю людського знання. Без сумніву, в перспективі вона повинна стати потужним інструментом вирішення різноманітних проблем, серед яких: запобігання невиліковним та спадковим хворобам, отримання практично цінних продуктів із відходів сільського господарства, очищення екологічно забруднених територій. В той же час з новітні біотехнологіями пов'язано багато ризиків. Однією з основних причин цього $є$ те, що 
біотехнології використовують, зокрема, генно-інженерні методи маніпулювання спадковим матеріалом живих організмів.

Надзвичайної актуальності у суспільстві ризику набувають морально-етичні питання трансгуманізму. Більше того, нанобіотехнології в поєднанні із більш грунтовним науковим розумінням роботи людського мозку може дати новий поштовх для виникнення соціальної інженерії, від якої, у вигляді євгеніки, відмовились вчені двадцятого століття [12, с. 26]. I, хоча час практичної реалізації пов'язаних з трансформацією людьми нанобіотехнологічних проектів ще не наступив, вже сьогодні актуальними стають питання: як зміниться соціальна, політична, економічна та інші сфери життя суспільства за умови впровадження генної інженерії людини у реальність.

Таким чином, розвиток біоетичної науки сигналізує про необхідність урівноваження, узгодження, гармонізації потреб людини та можливих негативних наслідків науково-технічного прогресу, покликаного ці проблеми розв'язати. 3 цих причин абсолютно обгрунтованою є дискусія щодо регламентації нанобіотехнологій та контролю їх практичного використання на рівні вищих управлінських структур. Зазвичай, здійснювати державний контроль над розвитком і впровадженням нанобіотехнологій досить складно. Ф. Фукуяма пропонує, попри масу складнощів, організовувати міжнаціональний контроль над дослідженнями у сфері нанобіотехнологій. Такого контролю, на його думку, можна досягти шляхом типового набору дипломатичних інструментів, серед яких - переговори та використання економічних і політичних важелів впливу. 3 іншого боку, на думку Я. Зодерквіста та О. Барда, позиції держави постійно послаблюються в порівнянні зі зростаючою силою мультинаціональних біотехнологічних компаній $[1$, c. 164]. Доступ до необхідної інформації допомагає вишукувати найсприятливіші умови для здійснення передових генетичних досліджень на терені країн, законодавча база яких є більш м'якою щодо розвитку нанобіо-технологій.

Подальший безпечний розвиток названої тенденції потребує удосконалення методів управління усім новим комплексом досліджень і практичних розробок. Отже, впровадження ефективної регламентації нанобіотехнологічної галузі здійснити не так просто, а це, очевидно, $€$ вкрай необхідним. Однак, зважаючи на невпинність технічного про- 
гресу та його нездатність йти назад, очевидним стає те, що неможливо просто викреслити нанобіотехнології із процесу розвитку сучасної цивілізації. Варто пам'ятати, що розвиток культури може бути трактований як процес релятивізації культурних цінностей. Проектуючи даний погляд на сучасне українське суспільство, очевидною стає актуальність столітньої давності ідей Г. Зіммеля про спустошення культурних форм, про розростання прірви між формою та змістом, що супроводжується індивідуалізацією людини. Індивідуалізація є загальносвітовою тенденцією, яка супроводжує процес глобалізації. Економіка, що глобалізується, «породжує, як відомо, все глибший розрив між процвітаючими і бідуючими шарами населення» [2, с. 98].

У суспільстві ризику людина сконцентрована на задоволенні простих і найнеобхідніших фізичних потреб. Саме поняття «виживання», яким характеризують такий стиль життя, констатує стан нездоров'я суспільства, значний розрив між потребами людини і можливостями їх задоволення. В такій ситуації нівелюються актуальність будь-яких культурних форм, моралі та інших соціальних нормативів і першочерговою стає проблема підтримання життя людини. В даному контексті влучно звучать слова Г. Зіммеля про те, що життя «бажає того, що повністю недосяжне для нього, - воно прагне проявити себе у своїй голій безпосередності поза всякими формами» [8, с. 79].

Оскільки нанобіотехнології є потужним засобом впливу на фізичне здо-ров'я людини, затребуваність таких методів у сучасному суспільстві досить висока, хоча позитивне значення і користь нанобіотехнологій для однієї людини може потенційно обернутись низкою негативних явищ і тенденцій, або навіть трагедією для суспільства. Тому необхідним $є$ урівноваження науково-технічного прогресу відповідним рівнем розвитку культури людини і культури суспільства.

Слід зауважити, що коли термін «нанобіотехнологія» вживають відносно людини, по суті, вказується на використання людського тіла у технологічних цілях, коли людина стає частинкою типового біотехнологічного процесу, тобто умовно перетворюється на біологічний агент (серед поживного середовища, устаткування і фізико-хімічних умов процесу), за допомогою якого можна отримати практично цінний продукт. Специфіка вживання терміну «нанобіотехнології» в філософiї пов'язана із людиноцентичністю гуманітарних наук. Біологічні 
технології, особливо при використанні генетичної інженерії, мають потенціал змінювати людське тіло, причому наслідки можуть бути як дуже позитивними, так і неочікувано та необоротно негативними. Це, зрозуміло, стало однією із рушійних сил розвитку біоетичних наук. Для вчених, що мають справу із технічною та технологічною стороною нанобіотехнологій, на перший план виступає ефективність застосування конкретної технології у промисловості. У суспільстві ризику перед філософією постали питання: чи варто людству так рішуче впроваджувати у життя нанобіотехнологічні здобутки? До якої межі людина як антропосоціальна істота може змінювати себе, щоб не втратити себе як людину?

Ф. Фукуяма 3 цього приводу зазначає: «...якщо ми хочемо знайти джерело цього переважаючого морального статусу людини, який ставить нас над усіма іншими тваринами і при цьому робить нас рівними один з одним як людей, нам потрібно дізнатись більше про ту підмножину властивостей людської природи, які не просто типові для нашого виду, але специфічні тільки для нього. І лише тоді ми будемо знати, що найсильніше за все треба захистити від майбутнього розвитку біотехнологій» [12, с. 197].

Таким чином, біотехнології і антропосоціокультурні практики у XXI ст. демонструють людині ступінь їі віддаленості від своєї внутрішньої суті, ії відчуження від самої себе. Не пройшовши стадії самоідентифікації як виду, людина не може свідомо рухатись вперед в ногу 3 технологічним прогресом. Квінтесенція раціональних спроб людини взяти контроль над природою, трансформувавшись у концепцію ноосфери та призначивши своєю правою рукою нанобіотехнології, наразі стикнулася з фундаментальною екзистенційно-онтологічною проблемою - проблемою існування людини. Декартівське «Cogito ergo sum» відводить індивіда від внутрішнього духовного-екзистенційого єства, внаслідок чого виникає двояка проблема: 3 одного боку, чи можна сучасну людину, яка цілком не розуміє хто вона $\epsilon$, назвати в повній мірі здоровою, а з іншого, чи можна назвати здоровим суспільство, яке складається із таких індивідів? Однак людина, яка б не стикнулася 3 цим аспектом проблеми самовизначення за допомогою проблеми фізичного здоров'я і нанобіотехнологій, не мала би потреби у самоусвідомленні на такому рівні. Отже, здоров'я є сферою, де людина може 
черпати смисл, через засвоєння якого вона здатна рости над собою. Також очевидним стає те, що дані ідеї можуть бути справедливими і для суспільства в цілому.

М. Бердяєв вважав, що техніка ослаблює активність людського духу, роблячи людину лише частинкою виробничого процесу: «це і $є$ відчуження людської природи і руйнування людини» [4, с. 303]. Вищесказане стосується і біотехнологій, адже людина як елемент складних людиномашинних систем майже у прямому значенні трансформується в механізм, елементи якого теоретично можуть підлягати ремонту і заміні. Це також віддаляє індивіда від самого себе, адже такі технології проблему нездоров'я беруть на себе. У даних умовах здоров'я може десакралізуватися і може зникати необхідність духовної активності людини, а фокус на вертикалі цінностей людського духу зміщуватися від духовного до тілесно-матеріального. Біотехнології можуть стати останнім етапом у перетворенні здоров'я людини на реальний товар, який можна буде купити в обмін на визначену суму грошей. Варто зауважити, що Г. Зіммель проводив влучну аналогію між грошима і проституцією, аргументуючи байдужість при передачі грошей та їх непов'язаність із суб' єктом [8]. Трансформація здоров'я у товар - сприятливий аргумент на підтримку деморалізації та прагматизації суспільства.

У суспільстві споживання соціум набуває рис суспільства споживання. У таких умовах, коли особисті інтереси однієї людини стають пріоритетними відносно потреб великої кількості людей, можна констатувати факт підвищеної вірогідності розгортання небезпек, пов'язаних із біотехнологіями і новітніми антропосоціокультурними практиками. До таких небезпек можна віднести, до прикладу, можливість ведення аморальних генетичних досліджень, нерегламентованої апробації потенційно небезпечних фармацевтичних препаратів на людях та ін. У суспільстві ризику, де відбувається комерціалізація духовних цінностей, необхідним є ретельний державний контроль над біотехнологіями і антропосоціокультурними практиками, які безпосередньо пов'язані із впливом на людину. У суспільстві ризику є потенційна перспектива створення неконтрольованої біологічної субстанції, вірусу, мікроорганізму, наноробота, здатних заподіяти шкоду людству. Ф. Фукуяма з цього приводу заспокоює: «Якщо ви знаєте, що вас уб'є машина, яку ви створили, то ви передбачите якісь міри 
захисту» [12, с. 17]. Якщо американський вчений і правий, то навіть зараз біотехнології в контексті проблеми відчуження мають всі шанси відділитись від людини, зробивши ії залежною від благ, пропонованих даними науками.

Генетична інженерія може впливати безпосередньо на тілесну складову людини. Проте, без відповіді поки що залишається питання: як зміниться нематеріальна складова людини - ¥ї мораль, алгоритми мислення, характер та ін.? біотехнологія може зберегти «внутрішній природний світ» людини, природне в ній, проте біотехнології $є$ не лише способом впливу людини на навколишнє середовище, але і на саму себе. Проте, безумовно, для безпечної реалізації біотехнологічних проектів, необхідним є відповідний рівень культури людини. Отже, наявною $є$ потреба змін у традиційному філософському осмисленні біологічних технологій. Видимим $є$ органічний зв'язок між конкретним біологічним дослідженням і його рефлексивно-методологічною оцінкою, що відображається в різноманітних епістемологічних моделях на різних етапах розвитку цивілізації. Це означає залежність застосовуваних до конкретної науки когнітивних стратегій від соціокультурних характеристик конкретної цивілізації. Вважається, що некласична наука зараз знаходиться на такому рівні розвитку, що увага має приділятись не тільки об'єкту їі дослідження, але і суб' єкту також, однак потрібно зауважити, що адекватність такої оцінки залежить від соціальної реальності, у якій існує такий суб'єкт, тобто від здоров'я суспільства. Останнє $\epsilon$ необхідним для адекватного користування високотехнологічними продуктами науково-технічного прогресу. 3 іншого боку, біотехнології ні при якому рівні гуманізації ії застосування не можуть перестати бути технологіями. Генна інженерія людини, зі всіма зі всіма спірними сторонами даного методу, продовжує інтегрувати людину у світ техніки, і людина, включаючись у техносферу, і далі стає елементом технічної реальності.

Безсумнівно, техніка змінила людину, особливо за останні кілька десятиліть. Темп життя значно зріс, і завдяки поширенню техніки у побуті в людини з'явилось більше вільного часу, який не завжди використовується нею для духовного саморозвитку та творчої реалізації. Висловлюючись словами Е. Фрома, людина «добилася «свободи від», але не досягла «свободи для», тобто свободи бути самою собою, бути продуктивною і повні- 
стю пробудитись» [11, с. 404]. Людина перетворюється на машину у метамеханізмі добування та розподілу матеріальних цінностей. Ф. Фукуяма привніс застереження щодо того, чи не стануть біотехнології проміжною сходинкою або навіть завершальним етапом перетворення сучасної людини у члена суспільства пост-людської ери [12].

Розвиток біотехнологій формує нову реальність - біотехносферу, де живе лишається біологічним, але вже не суто природним, а це створює базу для формування нових взаємовідносин природи та техніки, а отже людини і природи, людини і суспільства.

\section{3. Здоров'я людини у нанобіотехнологічному суспільстві}

Актуальність дослідження нанобіотехнологічних впливів на людину $є$ поштовхом для розробки концепції біотехнологічного суспільства як тріади «біотехнології - загальна структура суспільства - ментальність». Зміни ментальності людини супроводжують зміни типів суспільства і з необхідністю переосмислення взаємодії у тріаді «здоров'я - ментальність - нанобіотехнології». Ментальність як система думок, вірувань, навичок духу, що створюють відносно цілісну картину світу і об'єднують культурну традицію суспільства, незаперечно пов'язана із здоров'ям людини, пов'язана зі свідомістю людини, вживлена у іiі екзистенційно-персоналістичну та світоглядну складову. Здоров'я $є$ певною матрицею, на якій може формуватися уявлення про світ, про живу і неживу природу. Як відомо, нирки та серце мають невелику здатність до регенерації, але печінка - це орган людини, що має здатність до відновлення, і відображення цього знання є навіть у міфології - це міф про Прометея. Подібні вірування та уявлення $є$ складовою частиною людського світогляду, який протягом тривалого часу складався у наших предків і став витоком поведінкових реакцій соці-окультурного характеру. Однак, медико-біотехнологізація здоров'я дозволила заміняти пошкоджену нирку на здоровий донорський орган. Стереотип, що при втраті нирки хворій людині може допомогти лише інша людина, руйнується з появою новітніх нанобіотехнологічних методів, котрі дають надію на можливість штучно створювати новий орган «у пробірці» та пересаджувати його хворій людині.

В контексті філософії ці нові можливості мають грунтовні та далекоглядні наслідки як для людської ментальності, так і для соціокуль- 
турного життя, адже нанобіотехнологія втручається у сферу взаємовідносин «людина-людина», замінюючи іiі у конкретних прикладах на відносини «людина-техніка». Отож, в контексті соціально-філософського аналізу тріади «здоров'я - ментальність - біотехнології» очевидним $\epsilon$ опосередкований вплив нанобіотехнологічних здобутків через людське здоров'я на ментальність людини та на сферу взаємовідносин «людина-людина». Нанобіотехнологізація здоров'я може призвести до змін світогляду людини в сторону технократичного мислення, адже цінність технологій у очах деяких людей має потенціал перерости цінність людини. На тлі духовно-моральної та ціннісно-нормативної криз соціуму це є несприятли-вим фактором для формування здоров'я суспільства. «При клонуванні людина ніби сама себе роздвоює на донора і реципієнта» [10, с. 99]. Таким чином, нанобіотехнології через здоров'я торкаються проблеми одинокості людини. Клітинна та тканинна інженерія дає людині перспективу бути донором для самої себе. Допомогу тепер не потрібно чекати від собі подібного у суспільстві, адже собі подібного можна виростити в лабораторних умовах із власного ж вихідного матеріалу. Завдяки нанобіотехнологіям хворий індивід для себе сам може стати ціллю і засобом, тому дещо девальвується роль іншої людини у врятуванні життя індивіда. Індивідуалізація в даній ситуації може мати відтінок вже не адаптації до несприятливих соціально-економічних умов, а зміни поведінкових нормативів у соціальному бутті людини.

У контексті здоров'я людини у суспільстві ризику варто також згадати і про феномен дихотомії людського знання на так зване «небезпечне» та «попереджувальне» знання. Об'єктивна наука, в тому числі i нанобіотехнології, $є$ потенційно небезпечною для людства, і для мінімізації цієї безпеки формуються нові види знання, покликані формувати необхідну культуру свідомості при користуванні новітніми технологіями. Для нанобіотехнологій «попереджувальним знанням» $€$ біоетика. Біосоціальність природи людини в наш час стала причиною загострення біоонтологічних проблем у розрізі життя суспільства. Констатується поява нової стратегії суспільного розвитку - стратегії вітальності, тобто налагодження консенсусу між валеологічними, екологічними, морально-правовими та етнічними аспектами життя людини. 
Гуманітаризація проблеми людського здоров'я демонструє його зв'язок не лише з матеріальним світом, але і також зі світом духовним, показує його інтегрованість як у персональне соматичне буття людини, так і у соціокультурну реальність, у буття суспільства. Сходження проблеми здоров'я людини до вершин піраміди цінностей сучасного індивіда спонукає його більш уважно ставитись до даної проблеми, що обумовлює потребу пошуку причинно-наслідкових зв'язків між людиною і природою та суспільством. Проблема людського здоров’я у площині суспільної свідомості ставить здобутки новітніх технологій у статус потенційної панацеї від багатьох страждань, стаючи вагомою підтримкою для політичних, економічних та соціальних сил, зацікавлених у проведенні сумнівних в моральному плані досліджень, а також форсуванні впровадження нанобіотехнологічних інновацій у життя. У суспільстві ризику відсутня чітка межа розподілу між нанобіотехнологіями, направленими на допомогу людині, та нанобіотехнологією, покликаною повністю людину трансформувати. Лікарня має бути тим місцем, де до людини ставляться по-людськи, не як до механізму, а саме $з$ позицій гуманізму. Відповідь на запитання, чи є здоровим ставлення людини до себе самої, як до механізму, співпадає із відповіддю на питання: «чи є людина механізмом». Виходячи з того, що людина це духовна істота, то будь-яке творіння людини - це творіння iіi духу. У філософському осмисленні модусу здоров'я, в аспекті соціального здоров'я, очевидним $\epsilon$ те, що біотехнології можуть дати індивіду ще один шанс змінитись; зрозуміти те, чого він не зміг би усвідомити, якби помер через втрату життєво важливих органів, або їх нездатність продукувати вітально необхідні метаболіти. Саме тут закладений соціально-етичний імператив процесу нанобіотехнологізації суспільства. Ідея трансформувати або клонувати людину є бажанням матеріалізувати ідею на такому ж рівні, на якому іï дотепер здатна була матеріалізувати лише природа (не в натурфілософському розумінні). Відтак, перебуваючи на вістрі нанобіотехнологічної революції, людина знаходиться на шляху самовідчуження.

Сучасна людина лише бере до відома те, що вона $\epsilon$ невід'ємною частинкою лише природи, а не буття космосу в цілому. Високотехнологічні здобутки наукової думки спонукають до розширеного розуміння людиною самої себе, до ставлення до себе як до людини, а не 
як до механізму, мислячої істоти чи політичної тварини, як до хворого або здорового. Персональний духовний стан людини як «турбота про себе» безпосередньо пов'язаний з її здоров'ям.

Сучасні високі технології дозволяють людині освоювати біосферу для покращення і продовження свого життя. Незнищенність цивілізації, на думку В. Вернадського, забезпечена ще й тим, що «вперше поставлена ... проблема свідомого регулювання розмноження, продовження життя, ослаблення хвороб для всього людства» [6, с. 50]. Біотехнології сприяють боротьбі людині з хворобами за допомогою антибіотичних препаратів. Застосування біотехнологічних методів у фармацевтичній індустрії створили нові можливості для виробництва вітамінів, гормонів, імуномодуляторів, медичних ферментів, медичних амінокислот, кровозамінників та інших засобів боротьби за життя і здоров'я людини. Сучасні футурологи дискутують 3 приводу можливості зміни геному людини, тобто відбору індивідів з найкращим генетичним матеріалом [12]. Дії такого роду могли б позбавити вид Ното sapiens від хвороб взагалі. Таким чином, розвиток нанобіотехнологій сьогодні став потужним засобом, завдяки якому людина здатна вести діалог 3 природою на принципово іншому рівні, з одного боку захищаючи себе, а з іншого - піддаючи ризикам неочікуваних наслідків свого втручання в організоване природою життя. В. Вернадський зазначав, що для становлення ноосфери на теренах людського буття необхідним $\epsilon$ початок домінування геологічної ролі людства над іншими геологічними процесами, що мають місце у біосфері. Таким чином, науковий прорив у галузі нанобіотехнології є одним із інструментів, який здатний нести зміни у планетарному масштабі. «Ноосфера - останній із багатьох станів еволюції біосфери в геологічній історії» [6, с. 510]. Проблема здоров'я - це проблема формування ноосферного мислення людини, еволюція iіi духу і шанс людини жити у майбутньому без хвороб. Якщо ж розвивати лише нанобіотехнології, ігноруючи планетарне мислення людини та iї духовний розвиток, то ситуації ризику для життя і здоров'я людини будуть повторюватись все частіше.

Уже сучасний рівень розвитку нанобіотехнологій дає людині можливість замінити зношений орган, ніби деталь в автомобілі. Нанобіотехнологізація людини як живої природної істоти здатна не лише через заміну органів покращувати здоров'я і продовжувати життя, але 
й впливати на внутрішні екзистенційні переживання людини, сферу іiі смисложиттєвих цінностей. У суспільстві ризику з високорозвиненою наукою і новітніми технологіями всі біотехнологічні і генно-інженерні маніпуляції з живими організмами мають бути чітко виваженими та продуманими; також необхідно прагнути враховувати всі передбачувані ризики і негативні результати втручання в природу [3]. На сьогодні вчені довели, що генна інженерія підвищує свободу міграції генів між організмами, котрі природним чином не можуть схрещуватись. Це явище потенційно може створювати загрози як для людини, так і для всього суспільства.

У контексті теорії Ч. Дарвіна постає проблема впливу природного відбору на хід еволюції. Якщо людина сама зможе змінювати свій геном, то чи буде йти еволюція звичним шляхом? Чи не перейдуть критерії природного відбору із біологічної сфери у сферу економічну і тим самим загостриться проблема соціальної справедливості та низка проблем морально-етичного характеру? Ф. Фукуяма ставить питання так: яким чином зміниться соціальна стратифікація, коли у суспільстві 3'явиться каста надлюдей на противагу тим, кому здобутки генетичної інженерії будуть не доступні з причин їх високої вартості?

Незважаючи на те, що в останні роки філософія продовжує досить активно утверджуватись у сфері біоетики, ставлення сучасного суспільства до нанобіотехнологій дуже нерівномірне і часто має місце як повне прийняття нанобіотехнологій, так і повне їх заперечення. У суспільстві ризику відмічається тенденція зниження технічної та природничо-наукової обізнаності населення навіть технологічно високорозвинутих країн. Важливою рисою сучасної науки $є$ те, що процес соціальної верифікації наукових новинок в більшій мірі залежить від неспеціалістів, а іноді і від ще менш компетентного суспільства загалом, і більшість людей не володіє достатніми знаннями для сприйняття наукової інформації. Дану ситуацію теж можна охарактеризувати як стан нездоров'я у суспільному масштабі, адже вона характеризується відсутністю, до прикладу, відповідності між рівнем наукової компетентності суспільства та рівнем розвитку науки. Складність раціонального аналізу наукової інформації в процесі формування ставлення суспільства до нанобіотехнологій виводить на перший план не логічну, а емоційно-чуттєву компоненту суспільної свідомості і сприйняття 
технократичного мислення як панування розсудку, якому чужі розум і муд-рість. Сприяти проблемі осмислення нанобіотехнологізації здоров'я людини може відповідь на моральне запитання, чим $є$ нанообіотехнології для сучасного суспільства - добром чи злом. Проте, очевидним $\epsilon$ те, що одними із можливих напрямків розвитку людства може бути шлях до кінця історії людини як виду Homo sapiens i початку нової пост-людської ери Ноmo electronicus. М. Бердяєв зазначав, що, потрібно «не заперечувати наукові відкриття техніки, а духовно оволодіти ними» [4, с. 303]. Так, нанобіотехнології ставлять людину в умови необхідності духовної активності для трансформації ціннісно-смислової парадигми у співзвучності із персональним соматичним буттям та зовнішнім соціокультурним буттям людини.

Динамічний розвиток нанобіотехнологій у XXI ст. актуалізує проблему свободи і відповідальності стосовно взаємовідносин «здоров'я соціум - нанобіотехнології». Це стосується перш за все промислового виробництва нанобіотехнології і, звичайно, проблеми свободи і відповідальності стосовно модусу здоров'я. Хвора людина завжди постає перед необхідністю, а питання застосування нанобіотехнологій пов'язане з узгодженістю свободи та відповідальності.

Духовне буття в масштабах суспільства $є$ сферою нематеріальних, вищих аксіологічних вузлів соціального буття. У контексті особистісного існування це може бути внутрішньо-особистісним екзистенційним континуумом, що характеризується орієнтацією на трансцендентні загальнолюдські цінності, такі як гармонія, добро, свобода, істина та ін. 3 точки зору філософії здоров'я, духовне означає ціннісно-смислову спрямованість індивіда на конституювання власної життєтворчості, на усвідомлення відповідальності за свої вчинки, здоров'я, конструктивність способу та стилю власного існування. Як зазначає Є. Бурцева, «особистість, що живе духовним виміром реальності, реалізує себе у творчій діяльності, спрямованій на перетворення універсуму і втілення в життя ідеалів абсолютних цінностей буття» [5]. Таким чином, з'ясування місця і ролі модусу здоров'я у системі аксіологічних детермінант соціального буття людини у суспільстві ризику містить у собі аналіз ціннісного статусу феномену здоров'я та співставлення даної величини із наявними тенденціями у сфері охорони здоров'я. 
У суспільстві ризику нанобіотехнології можуть виступати інструментом влади або сходинкою до прагматизації та десакралізації здоров'я. Проте, це не заперечує той факт, що нанобіотехнології є перспективним напрямком розвитку, зважаючи на високий інтелектуальний потенціал суспільства. Серед сучасних нанобіотехнологій - генетична інженерія, клітинна і тканинна інженерія, серед біотехнологій - промислова біотехнологія та харчова біотехнологія, яку часто плутають із популяризацією використання хімічних добавок при виробництві харчових продуктів з метою їх здешевлення та покращення їх якостей. Всі вони також інтегровані в економічне та політичне життя сьогодення, прямо чи опосередковано взаємодіючи з людським здоров'ям, та підтверджуючи важливість його місця у соціальному бутті людини.

Засобом дослідження місця здоров'я в системі цінностей людини у сучасному суспільстві є феномен медикалізації, і в масштабах суспільства духовне буття $є$ сферою нематеріальних, вищих аксіологічних вузлів соціального буття. У контексті особистісного існування - це може бути внутрішньо-особистісним екзистенційним континуумом, що характеризується орієнтацією на трансцендентні загальнолюдські цінності, такі як гармонія, добро, свобода, істина та ін. 3 точки зору філософії здоров'я, духовне означає ціннісно-смислову спрямованість індивіда на конституювання власної життєтворчості, на усвідомлення відповідальності за свої вчинки, здоров'я конструктивність способу та стилю власного існування.

У суспільстві ризику процес медикалізації ставить під медичний контроль такі проблеми як самоідентифікація особистості, спілкування та соціалізації індивіда. Свого часу Ф. Фукуяма писав про можливість через використання продуктів фармацевтичної індустрії змінювати людську особистість, підсилюючи деякі риси характеру, такі як самооцінку та здатність до зосередження. Таким чином, медикалізація окрім інженерного халата взяла до своїх рук і філософський посох, адже тепер людина звертається до лікаря у надії на те, що він краще знає їі організм, ніж вона сама. Більше того, проблема $є$ і у тому, що людський організм несвідомо ототожнюється власне із людиною. Звідси випливає, що вона звертається до медицини з проханням вилікувати себе від самої ж себе. Якщо філософія на це прохання відповіла б наголошенням на багатогранності та глибині проблеми, не беручись 
за безпосереднє лікування пацієнта, то медикалізація може поставити медицину у положення, яке вимушуватиме медицину робити «ведмежу послугу». За таких умов медицина здаватиметься панацеєю від всіх проблем, яка, однак, сміливо братиме на себе обов'язок їх самотужки і вирішити, хоч не завжди успішно.

\section{4. Висновки}

У суспільстві ризику при застосуванні нанобіотехнологій необхідним є дотримання принципу розумної доцільності. Медична наука збагачена філософським духом, $є$ значно ближчою до проблеми людського здоров'я загалом, а також і до проблеми здоров'я в дискурсі соціального буття людини. Медицина спеціалізується переважно на проблемах людського тіла, яке, однак, не вичерпує повноти людського буття. Дані питання потребують грунтовної філософсько-аналітичної рефлексії у контексті людського світогляду, адже торкаються проблеми ставлення людини до самої себе і до соціального оточення, до життя загалом. Медицина, безумовно, є принципово необхідною частиною соціальної сфери будь-якого суспільства, яке претендує хоча б на мінімальний розвиток. Проте, медицина являє собою багатогранний феномен, одним із проявів якого є медикалізація як процес, у ході якого різні аспекти людського життя починають розглядатися у якості медичної проблеми, стаючи інтегрованими у поле поміж двох амбівалентних полюсів: здоров'я і хвороби. Наслідком цього є як самоусвідомлення людиною себе пацієнтом, так і об'єктивація людського тіла і життя у площину медичного моніторингу та регулювання. Основною серед рушійних сил медикалізації можна виділити різнопланову соціально-економічну цінність здоров'я. Здоров'я $є$ соціально-економічною цінністю для індивіда та держави, в основі чого лежить утилітарне ставлення до здоров'я. Даний аспект феномену здоров'я може бути одним із бар'єрів щодо соціальної свободи індивіда у займанні економічно-бажаного суспільного статусу, а також мірилом ефективності накопичення капіталу індивідом для держави. 3 іншого боку, феномен людського здоров'я, а точніше його здатність визначати соціальну свободу людини, виступає у якості економічної цінності для виробників медичної техніки та ліків. Попит на них може забезпечуватися тією ж економічною цінністю здоров'я для індивіда, для якого проблеми зі здоров'ям приводять до зміні матері- 
ального статусу. У таких умовах наявний феномен патологізації існування суспільства і конкретної людини. Медикалізація у масштабах реальності індивіда може проявляється у тому, що він при перших же натяках хоча б на деяку фізичну слабкість чи якусь проблему в житті, звертається до адептів медицини, котрі покликані ліквідувати цю складність. Таким чином, медикалізація трансформує різні рівні суспільної суспільної свідомості, підводячи медицину впритул до взаємодії із людським світоглядом у сфері смисложиттєвості. Людиновимірність нанобіотехнологізації здоров'я полягає в опосередкуванні біологічними технологіями відносин людини з людиною, інтегруванні людини у техносферу та іiі перетворенні в елемент технічної реальності. Вирішення проблем зі здоров'ям за допомогою нанообіотехнологій веде до десакралізації здоров'я, зникнення необхідності духовної активності людини, зміщення акценту на вертикалі цінностей людського духу від духовного до тілесно-матеріального. За умов міфологі-зації нанобіотехнологій та природничо-наукової некомпетентності більшості населення, містифікації наукових досягнень та маніпуляції свідомістю при формуванні суспільної думки щодо впровадження нанобіотехнологічних здобутків у життя активується не раціональна, а емоційно-чуттєва компонента суспільної свідомості.

\section{Список літератури:}

1. Бард А., Зодерквист Я. Netoкратия. Новая правящая элита и жизнь после капитализма / Перевод с шведского языка. СПб. : Стокгольмская школа экономики в Санкт-Петербурге, 2004. 252 с.

2. Бауман 3. Индивидуализированное общество / Пер. с англ. под ред. В.Л. Иноземцева. Москва : Логос, 2005. 390 с.

3. Бейлин М.В. Нанотехнология как прорыв в постнеклассической науке: монография. Харків : ТОВ Оберіг, 2014. 480 с.

4. Бердяев Н.А. Царство духа и царство кесаря. Москва : Республика, 1995. C. $288-356$.

5. Бурцева Е., Кирсанова Л. Вина. Антропологические предпосылки. URL: http://institut.smysl.ru/burceva_kirsanova.php (дата звернення: 20.10.2019).

6. Вернадский В.И. Философские мысли натуралиста. Москва : Наука, 1988. $520 \mathrm{c}$.

7. Гурвич И.Н. Социальное здоровье. Санкт-Петербургский центр девиантологии, публикации. URL: http://deviantology.spb.ru/etc/publications/ Gurvich-Sotsialnoe_zdorovye.pdf (дата звернення: 18.10.2019).

8. Зиммель Г. Йзбранные работы / пер. с нем. Київ : Ника-Центр, 2006. 440 с. 
9. Косарев В.В. Трансгуманизм и синергетическая философия. Международные чтения по теории, истории и философии культуры (Дифференциация и интеграция мировоззрений). СПб., 2004. № 20. С. 296.

10. Тищенко П.Д. Био-власть в эпоху биотехнологий. Москва, 2001. 177 с.

11. Фромм Э. Здоровое общество. Догмат о Христе / пер. с нем. Москва : АСТ: Транзиткнига, 2005. $571 \mathrm{c}$.

12. Фукуяма Ф. Наше постчеловеческое будущее: Последствия биотехнологической революции / пер. с англ. М.Б. Левина. Москва : ООО «Издательство АСТ»; ОАО «ЛЮКС», 2004. 349 с.

\section{References:}

1. Bard A., Zoderkvist Ya. (2004). Netokratiya. Novaya pravyashchaya elita i zhizn' posle kapitalizma [Netocracy. The new ruling elite and life after capitalism]. $\mathrm{SPb}$.: Stokgol'mskaya shkola ekonomiki v Sankt-Peterburge. (in Russian)

2. Bauman Z. (2005). Individualizirovannoe obshchestvo [Individualized society]. Moskva: Logos. (in Russian)

3. Beylin M.V. (2014). Nanotekhnologiya kak proryv v postneklassicheskoy nauke [Nanotechnology as a breakthrough in post-non-classical science]. Khar'kov: TOV Oberig. (in Russian)

4. Berdyaev N.A. (1995). Tsarstvo dukha i tsarstvo kesarya [The kingdom of spirit and the kingdom of Caesar]. Moskva: Respublika, pp. 288-356. (in Russian)

5. Burtseva E., Kirsanova L. Vina. Antropologicheskie predposylki [Guilt. Anthropological premises]. Retrieved from: http://institut.smysl.ru/burceva kirsanova.php (accessed 20 October 2019). (in Russian)

6. Vernadskiy V.I. (1988). Filosofskie mysli naturalista [The philosophical thoughts of a naturalist]. Moskva: Nauka. (in Russian)

7. Gurvich I. N. Sotsial'noe zdorov'e [Social health]. Sankt-Peterburgskiy tsentr deviantologii, publikatsii [St. Petersburg Center for Deviant Studies, publications]. Retrieved from: http://deviantology.spb.ru/etc/publications/Gurvich-Sotsialnoe zdorovye.pdf (accessed 18 October 2019). (in Russian)

8. Zimmel' G. (2006). Izbrannye raboty [Featured Works]. Kiev: Nika-Tsentr. (in Russian)

9. Kosarev V.V. (2004). Transgumanizm i sinergeticheskaya filosofiya [Transhumanism and Synergetic Philosophy]. Mezhdunarodnye chteniya po teorii, istorii $i$ filosofii kul'tury (Differentsiatsiya i integratsiya mirovozzreniy) [International readings on the theory, history and philosophy of culture (Differentiation and integration of worldviews)]. SPb. No. 20. P. 296. (in Russian)

10. Tishchenko P.D. (2001). Bio-vlast' v epokhu biotekhnologiy [Bio-power in the era of biotechnology]. Moskva. (in Russian)

11. Fromm E. (2005). Zdorovoe obshchestvo. Dogmat o Khriste [Healthy society. Dogma of Christ]. Moskva: AST: Tranzitkniga. (in Russian)

12. Fukuyama F. (2004). Nashe postchelovecheskoe budushchee: Posledstviya biotekhno-logicheskoy revolyutsii [Our posthuman future: Consequences of the biotechnological revolution]. Moskva: OOO "Izdatel'stvo ACT"; OAO "LYuKS". (in Russian) 